\title{
GARLIC QUALITY AS A FUNCTION OF SEED CLOVE HEALTH AND SIZE AND SPACING BETWEEN PLANTS ${ }^{1}$
}

\author{
MAYKY FRANCLEY PEREIRA DE LIMA ${ }^{2 *}$, WELDER DE ARAÚJO RANGEL LOPES ${ }^{3}$, MARIA ZULEIDE DE \\ NEGREIROS $^{3}$, LEILSON COSTA GRANGEIRO ${ }^{3}$, HIAGO COSTA DE SOUSA ${ }^{3}$, OTACIANA MARIA DOS \\ PRAZERES DA SILVA ${ }^{3}$
}

\begin{abstract}
Garlic has a worldwide economic importance; this vegetable can be consumed fresh or processed by food industries. However, few studies evaluate its postharvest quality. It is necessary to establish cultural practices and methods that focus not only on increase of yield, but on obtaining a product with better postharvest quality. The objective of this work was to evaluate the bulb quality of conventional garlic and virus -free garlic as a function of seed clove size and space between plants. Two experiments were conducted simultaneously in Portalegre, Rio Grande do Norte, Brazil. A randomized block experimental design with four replications was used in both experiments. The treatments were arranged in split-plots, with the seed clove size (large and small) in the plots, and the plant spacings $(7.5,10.0,12.5$, and $15.0 \mathrm{~cm}$ between plants) in the subplots. The use of large seed cloves resulted in higher bulb diameter and titratable acidity (TA). Soluble solids (SS), total soluble sugars, SS to TA ratio, and total solids decreased as the space between plants was increased, regardless of the seed health and seed clove size. Virus-free garlic seed cloves planted with spacing of 12.5 and $15.0 \mathrm{~cm}$ resulted in higher bulb diameter, TA, pungency, and industrial index, i.e., they produced better quality bulbs with good prospects for industrialization.
\end{abstract}

Keywords: Allium sativum L. Soluble solids. Pungency. Industrial index.

\section{QUALIDADE DE ALHO EM FUNÇÃO DA SANIDADE, TAMANHO DO BULBILHO E ESPAÇAMENTO ENTRE PLANTAS}

\begin{abstract}
RESUMO - O alho é uma hortaliça que possui grande importância econômica mundial, podendo ser consumido de forma in natura ou industrializado. Mesmo assim, poucos trabalhos envolvendo a análise da qualidade pós-colheita são encontrados. Desta forma, é necessário estabelecer práticas e métodos de cultivo que visem à obtenção não só do aumento da produtividade, mas também, de um produto de melhor qualidade póscolheita. O objetivo deste estudo foi avaliar a qualidade de bulbos de alho nobre convencional e livre de vírus em função do tamanho do bulbilho e do espaçamento entre plantas. Dois experimentos foram conduzidos simultaneamente, utilizando alho livre de vírus e convencional, em Portalegre-RN. O delineamento experimental adotado, em ambos os experimentos, foi de blocos casualizados, com quatro repetições. Os tratamentos foram dispostos em parcelas subdivididas, sendo as parcelas representadas pelo tamanho dos bulbilhos: grande e pequeno. As subparcelas foram compostas por quatro espaçamentos entre plantas: 7,5; 10,0; 12,5 e $15,0 \mathrm{~cm}$. O uso de bulbilho grande proporcionou maior diâmetro de bulbo e acidez titulável. Os teores de sólidos solúveis, açúcares solúveis totais, relação SS/AT e sólidos totais diminuíram com o aumento dos espaçamentos entre plantas, independente da sanidade e tamanho de bulbilho utilizado. $\mathrm{O}$ alho livre de vírus e os espaçamentos entre 12,5 e 15,0 cm promoveram maior diâmetro de bulbos, acidez titulável, pungência e índice industrial, possibilitando a produção de bulbos com melhor qualidade e com boas perspectivas para a industrialização.
\end{abstract}

Palavras-chave: Allium sativum L. Sólidos solúveis. Pungência. Índice industrial.

\footnotetext{
${ }^{*}$ Corresponding author

${ }^{1}$ Received for publication in 04/29/2019; accepted in 07/11/2019.

Paper extracted from the doctoral thesis of the first author.

${ }^{2}$ Department of Mathematics and Statistics, Universidade do Estado do Rio Grande do Norte, Mossoró, RN, Brazil; maykylima@bol.com.br - ORCID: 0000-0002-4405-7354.

${ }^{3}$ Department of plant sciences, Universidade Federal Rural do Semi-Árido, Mossoró, RN, Brazil; welder.lopes@hotmail.com - ORCID: 0000-0002-9380-6710, zuleide@ufersa.edu.br - ORCID: 0000-0002-0665-326X, leilson@ufersa.edu.br - ORCID: 0000-0002-4613-3605, hiagocsousa@gmail.com - ORCID: 0000-0003-3109-6407, otaciana_silva@yahoo.com.br - ORCID: 0000-0002-0634-5419.
} 


\section{INTRODUCTION}

Garlic is a well-appreciated vegetable worldwide due to its flavor, aroma, spice, and medicinal properties (OLIVEIRA et al., 2010).

Most garlic in Brazil is marketed fresh, but in recent years, it has been used in industrialized products that are well accepted by consumers, such as garlic paste and dehydrated garlic, adding value to this product.

The adoption of new technologies for garlic production is important because of the increasing demand of the food market, including virus-free garlic seeds and cultural practices for the field phase, which can enable garlic to reach the market with better quality for the consumers.

The use of virus-free garlic seeds has resulted in plants with greater vigor, mainly due to the absence of degenerations caused by viruses. Consequently, these plants have greater bulb yield than those from conventional seeds, and bulbs with better quality and good prospects for food industries, adding value to the product (RESENDE et al., 2013).

Determining the bulb pungency is important for the analysis of garlic quality; it depends on the concentration of pyruvic acid, which is responsible for the characteristic garlic flavor and aroma. Bulbs with high concentration of pyruvic acid are desirable because it is responsible for the industrial yield (industrial index); this is essential for choosing the raw material for processing, because the higher this concentration the higher the pungency of the flavor and aroma of the final product, which are characteristics desired by consumers (VARGAS et al., 2010; LUCENA et al., 2016).

Other factors of crop management can improve bulb quality, such as the space between plants and the seed clove size used for planting. Some researchers have reported the effect of plant population and seed clove size on postharvest conservation and commercial quality of garlic bulbs, indicating the most appropriate processing and dehydration treatments for the industry.

According to Randle (1997), chemical composition and sensory characteristics of flavor and aroma depend more on genetic factors than on crop conditions, but the bulb chemical composition and flavor intensity are also dependent on plant development conditions and also on crop management practices, such as planting density and seed clove size.

Studies in several garlic producing regions in Brazil have evaluated garlic plant growth and yield as a function of plant population and seed clove size. However, few of them consider the postharvest quality, which is important for choosing cultivars, crop managements, and the acceptance by the consumer market. Thus, the objective of this work was to evaluate the bulb quality of conventional garlic and virus-free garlic as a function of seed clove size and plant spacing.

\section{MATERIAL AND METHODS}

Two experiments were conducted, one with conventional garlic seed cloves (infected with virus), and other with virus-free garlic seed cloves obtained from the Brazilian Agricultural Research Corporation (EMBRAPA). The experiments were carried out simultaneously from May to September 2017, in Portalegre, state of Rio Grande do Norte, Brazil (6 $1^{\circ} 20^{\prime \prime} \mathrm{S}, \quad 38^{\circ} 1^{\prime} 45^{\prime \prime} \mathrm{W}, 520 \mathrm{~m}$ altitude). According to the Köppen classification, the region has an Aw, tropical rainy climate, with a dry winter, a rainy season extending to July, and an annual average rainfall depth of 800 to $1,200 \mathrm{~mm}$. The air temperature was monitored during the experiment, showing averages of 15 to $21^{\circ} \mathrm{C}$ (minimum), $24.7^{\circ}$ $\mathrm{C}$ (average), and 26 to $34{ }^{\circ} \mathrm{C}$ (maximum).

The soil of the area where the garlic was produced was classified as a eutrophic Neossolo Litolico of weak A horizon and a medium texture (EMBRAPA, 2018). The chemical analysis of the soil showed $\mathrm{pH}\left(\mathrm{H}_{2} \mathrm{O}\right)$ of $4.60,4.97 \mathrm{~g} \mathrm{Kg}^{-1}$ of organic matter, $0.07 \mathrm{~g} \mathrm{~kg}^{-1}$ of $\mathrm{N}, 5.3 \mathrm{mg} \mathrm{dm}$ of $\mathrm{P}, 79.7 \mathrm{mg}$ $\mathrm{dm}^{-3}$ of $\mathrm{K}, 8.9 \mathrm{mg} \mathrm{dm}^{-3}$ of $\mathrm{Na}, 2.6 \mathrm{cmol} \mathrm{dm}^{-3}$ of $\mathrm{Ca}$, $1.3 \mathrm{cmol} \mathrm{dm}^{-3}$ of $\mathrm{Mg}, 0.1 \mathrm{cmol} \mathrm{dm}^{-3}$ of $\mathrm{Al}$, and base saturation of $64 \%$

The experiments were conducted in a randomized block design with four replications. The treatments were arranged in split plots. The plots consisted of bulb sizes: large [bulbs retained in sieves $1(15 \times 25 \mathrm{~mm})$ and $2(10 \times 20 \mathrm{~mm})]$; and small [bulbs retained in sieves $3(8 \times 17 \mathrm{~mm})$ and $4(5 \times 17$ $\mathrm{mm})$ ]. The subplots consisted of spacings between plants: $7.5,10,12.5$, and $15 \mathrm{~cm}$ between plants, with $20 \mathrm{~cm}$ between rows, corresponding to planting densities of $500,375,300$, and 250 thousand plants per hectare, respectively.

The virus-free garlic seed cloves had average weights of 1.51 to $2.32 \mathrm{~g}$ (large size) and 0.83 to $0.98 \mathrm{~g}$ (small size); and the conventional garlic seed cloves had average weights of 1.87 to $2.61 \mathrm{~g}$ (large size) and 0.91 to $1.28 \mathrm{~g}$ (small size).

The garlic cultivar used was the Roxo Pérola de Caçador. The garlic clove seeds underwent a vernalization process for 50 days in a cold chamber at $4 \pm 2{ }^{\circ} \mathrm{C}$ and relative humidity of approximately $70 \%$. The bulbs were withdrawn from the cold chamber at one day before planting for threshing and, then, they were classified by size, according to Regina and Rodrigues (1970), and planted according to the treatments.

The subplots consisted of beds with height of $0.2 \mathrm{~m}$, width of $1.0 \mathrm{~m}$, and lengths of $1.50,2.00,2.50$ or $3.00 \mathrm{~m}$, according to the spaces between plants of the treatments $(7.5,10,12.5$, and $15 \mathrm{~cm})$, with five planting rows, totaling 100 plants. The evaluation area of the subplots consisted of the three central 
rows, discarding one plant at each end of the rows, resulting in a population of 54 plants.

The soil preparation consisted of a plowing and harrowing, followed by the formation of the beds. Then, the soil acidity of the beds was corrected by uniformly incorporating $400 \mathrm{~kg} \mathrm{ha}^{-1}$ of $\mathrm{Ca}(\mathrm{OH})_{2}$. Fertilization at planting was based on the soil chemical analysis and recommendations of Cavalcanti (2008), using $30 \mathrm{~kg} \mathrm{ha}^{-1}$ of $\mathrm{N}$ (calcium nitrate), $\quad 180 \quad \mathrm{~kg} \quad \mathrm{ha}^{-1}$ of $\mathrm{P}_{2} \mathrm{O}_{5} \quad$ (simple superphosphate), $60 \mathrm{~kg} \mathrm{ha}^{-1}$ of $\mathrm{K}_{2} \mathrm{O}$ (potassium chloride), $15 \mathrm{~kg} \mathrm{ha}^{-1}$ of $\mathrm{Mg}$ (magnesium sulphate), $12 \mathrm{~kg} \mathrm{ha}^{-1}$ of $\mathrm{Zn}$ (zinc sulphate), $1.7 \mathrm{~kg} \mathrm{ha}^{-1}$ of B (boric acid), and $40 \mathrm{Mg} \mathrm{ha}^{-1}$ of a beef and chicken manure fertilizer (Pole Fértil ${ }^{\circledR}$ ) containing $1 \% \mathrm{~N}$ and $15 \%$ organic $\mathrm{C}$, with $50 \%$ moisture, $\mathrm{pH}$ of 6.0 , and CEC of $80 \mathrm{mmol}_{\mathrm{c}} \mathrm{dm}^{-3}$.

Topdressing was performed at 20 and 50 days after planting, using 30 and $60 \mathrm{~kg} \mathrm{ha}^{-1}$ of $\mathrm{N}$ with calcium nitrate and urea, respectively.

Weed control was carried out manually, maintaining the plants in a weed-free environment. Phytosanitary control was performed using mancozeb-based products to control purple spot. The control of pest, such as thrips and mites, was carried out using clorfenapir-based products.

Irrigation was performed using a micro sprinkler system, with flow of $40 \mathrm{~L} \mathrm{~h}^{-1}$, pressure of $200 \mathrm{KPa}$, and micro sprinklers spaced $1.0 \mathrm{~m}$ long in the subplots. Irrigation was suspended three days before harvest, when the plants presented signs of maturation-yellowing and partial drying of the aerial part. Harvesting was performed manually and the plants were subjected to a pre-cure process, remaining for three days exposed to the sun, and to a cure process, in which they remained for 17 days in a shaded, dry, ventilated place. Subsequently, the bulbs were cleaned and processed.

The diameters were measured using a sample consisted of 10 bulbs per subplot. These bulbs were then threshed, and their cloves were manually peeled, ground in a food processor, and analyzed for the following characteristics:

a) bulb diameter $(\mathrm{mm})$ : average of the crosssectional diameters of 10 bulbs of each subplot;

b) soluble solids (\%): determined directly from the homogenized garlic juice, which was filtered on a polyester fabric and read on a digital refractometer (Palette PR-100, Atago, Saitama, Japan); the results were expressed as percentages (AOAC, 2002);

c) total soluble sugars: quantified by the Antrona method, described by Yemm and Willis (1954); $0.2 \mathrm{~g}$ of garlic paste was diluted in distilled water in a volumetric flask to a volume of $100 \mathrm{~mL}$ and filtered to obtain the extract; $50 \mu \mathrm{L}$ of the extract and $950 \mu \mathrm{L}$ of distilled water were added to a test tube, which was subjected to an ice bath, while the Antrona solutions $(2 \mathrm{~mL})$ was added. The test tubes were then shaken and immediately returned to the ice bath and, subsequently, they were boiled over a water bath for eight minutes. Then, they were cooled on ice water. The standard curve was developed using glucose solution at concentrations of $0,10,20$, 30,40 , and $50 \mathrm{mg} \mathrm{L}^{-1}$. The solutions were read in a spectrophotometer at $620 \mathrm{~nm}$ and the results were expressed in $\mathrm{g} 100 \mathrm{~g}^{-1}(\%)$;

(d) titratable acidity: $1 \mathrm{~g}$ of garlic paste was diluted in distilled water to a volume of $50 \mathrm{ml}$. Two drops of $1 \%$ alcoholic phenolphthalein were added. Titration was performed with $0.1 \mathrm{~N} \mathrm{NaOH}$ solution to the turning point characterized by the pink color. Results were expressed as $\mathrm{mEq} \mathrm{H}_{3} \mathrm{O}^{+} 100 \mathrm{~g}^{-1}$ (IAL, 2005);

e) Soluble solids to titratable acidity ratio.

f) Pungency: estimated by determining the pyruvic acid content using 2,4dinitrophenylhydrazine reagent (DNPH), by the colorimeter method (SCHWIMMER; WESTON, 1961). An aliquot of $0.2 \mathrm{~mL}$ of garlic juice was placed in an Erlenmeyer flask, and $1.5 \mathrm{~mL}$ of $5 \%$ trichloroacetic acid and $18.3 \mathrm{~mL}$ of distilled water were added to obtain the extract. The solution was stirred and, then, $1 \mathrm{~mL}$ of the extract, $1 \mathrm{~mL}$ of 2,4 dinitrophenylhydrazine (DNPH) solution, and $1 \mathrm{~mL}$ of distilled water were added to a test tube. The solution was vortexed and the test tubes were placed in a water bath at $37^{\circ} \mathrm{C}$ for 10 minutes. The solution was cooled in an ice bath and $5 \mathrm{~mL}$ of $0.6 \mathrm{~N} \mathrm{NaOH}$ was added in each test tube. They were vortexed and left to rest for five minutes to develop a yellow color. Absorbances were read on a spectrophotometer at $420 \mathrm{~nm}$. Sodium pyruvate was used as standard. The pungency was calculated by drawing the standard sodium pyruvate curve at seven concentrations $(0.0$, $0.2,0.4,0.6,0.8,1.0$, and $\left.1.2 \mathrm{mmol} \mathrm{L}^{-1}\right)$. The results were expressed in $\mu$ Moles of pyruvic acid per $\mathrm{mL}$ of garlic juice;

g) total solids: seed cloves of a sample of ten bulbs were taken to a forced air-circulation oven at $65{ }^{\circ} \mathrm{C}$ until constant weight. The total solids were calculated by the difference between 100 and the moisture content of the seed cloves; the results were expressed as $\mathrm{g}$ of total solids per $100 \mathrm{~g}$ of garlic (\%) (IAL, 2005);

h) Industrial index: calculated by the formula Industrial index $=($ total solids $\times$ pyruvic acid $) 100^{-1}$, according to Carvalho et al. (1991).

The data were subjected to analysis of variance for each experiment separately. Observing the assumptions for homogeneity of variances and normality of errors between experiments, the data were subjected to joint variance analysis; the means related to bulb size and seed health were compared by the $t$ test $(p \leq 0.05)$; and the means related to plant spacing were compared by regression analysis and the F test $(p \leq 0.05)$. 


\section{RESULTS AND DISCUSSION}

The interaction between plant spacing and seed health was significant for bulb diameter. Seed health had significant effect on titratable acidity (TA), soluble solids to titratable acidity (SS to TA) ratio, pungency, total solids, and industrial index. Seed clove size had significant effect on TA, SS to TA ratio, and bulb diameter. Space between plants had significant effect on TA, SS, SS to TA ratio, total soluble sugars, pungency, total solids, and industrial index.
The bulb diameter (BD) of garlic plants from large seed cloves was higher than that of those from small seed cloves (Table 1). This is because plants from large seed cloves can have higher leaf area index than those from smaller ones, resulting in higher accumulation of photoassimilates and higher BD (CASTELLANOS et al., 2004). The higher carbohydrate and mineral reserves in large bulbs produce vigorous plants that establish faster and have better development when compared to those from smaller bulbs (LENCHA; BUKE, 2017). Similarly, Mahadeen (2011) reported that the seed cloves with lower weights affected bulb length and diameter.

Table 1. Average values of bulb diameter, titratable acidity, and soluble solids to titratable acidity ratio (SS/TA) of garlic as a function of seed clove size.

\begin{tabular}{cccc}
\hline Seed clove size & Bulb diameter $(\mathrm{mm})$ & $\begin{array}{c}\text { Titratable acidity }(\mathrm{mEq} \\
\left.\mathrm{H}_{3} \mathrm{O}^{+} 100 \mathrm{~g}^{-1}\right)\end{array}$ & SS/TA \\
\hline Small & $39.17 \mathrm{~b}$ & $5.69 \mathrm{~b}$ & $6.10 \mathrm{a}$ \\
Large & $41.83 \mathrm{a}$ & $6.06 \mathrm{a}$ & $5.71 \mathrm{~b}$ \\
\hline
\end{tabular}

Means followed by the same letter in the column do not differ by the Student's t-test $(p \leq 0.05)$.

The garlic seed health affected the BD; the plants from virus-free seeds had higher BD than the those from conventional seed in all the evaluated spacings between plants, with most bulbs in classes 4 (> 37 to $42 \mathrm{~mm}$ ) and 5 (> 42 to $47 \mathrm{~mm}$ ) (Table 2). This difference due to seed health is explained by the higher vigor of plants from virus-free seeds, higher plant height and number of leaves (data not shown), and, probably, higher net assimilation rate, which resulted in bulbs of larger transverse diameter. According to Henriques (2016), the increase in BD is related to the number and length of leaves and plant height, thus, plants with larger leaf area have higher production and translocation of photoassimilates for bulb growth.

Table 2. Average values of noble garlic bulb diameter as a function of garlic seed health in each space between plants evaluated.

\begin{tabular}{ccccc}
\hline & \multicolumn{4}{c}{ Bulb diameter $(\mathrm{mm})$} \\
\cline { 2 - 5 } Seed health & \multicolumn{4}{c}{ Space between plants $(\mathrm{cm})$} \\
\cline { 2 - 4 } & 7.5 & 10.0 & 12.5 & 15.0 \\
\hline Conventional & $36.48 \mathrm{~b}$ & $36.93 \mathrm{~b}$ & $38.60 \mathrm{~b}$ & $38.55 \mathrm{~b}$ \\
Virus-free & $39.41 \mathrm{a}$ & $42.94 \mathrm{a}$ & $45.95 \mathrm{a}$ & $45.14 \mathrm{a}$ \\
\hline
\end{tabular}

Means followed by the same letter in the column do not differ by Student's t-test $(p \leq 0.05)$.

Similarly, Resende et al. (2000) found higher bulb size with virus-free garlic cultivars. According to Marodin (2014), the use of virus-free garlic seeds results in $100 \%$ more large bulbs (diameter greater than $52 \mathrm{~mm}$ ) when compared to plants from conventional seeds; and the use of conventional garlic seeds results in a higher production of noncommercial bulbs (diameters lower than $32 \mathrm{~mm}$ ).

The BD of both garlic seeds (conventional and virus-free) increased as the planting spacing was increased, reaching BD of 38.73 (conventional) and
$45.65 \mathrm{~mm}$ (virus-free) in the spacing of $15.0 \mathrm{~cm}$ between plants (Figure 1).

Increases in $\mathrm{BD}$ due to lower plant densities was reported in other studies (AHMED et al., 2017; MUNEER et al., 2017). Lower plant densities result in greater sunlight incidence, higher photosynthetic rates, and lower competition between plants for nutrients and water, generating greater vegetative growth and bulbs with larger diameters (MORAVČEVIĆ et al., 2011). 


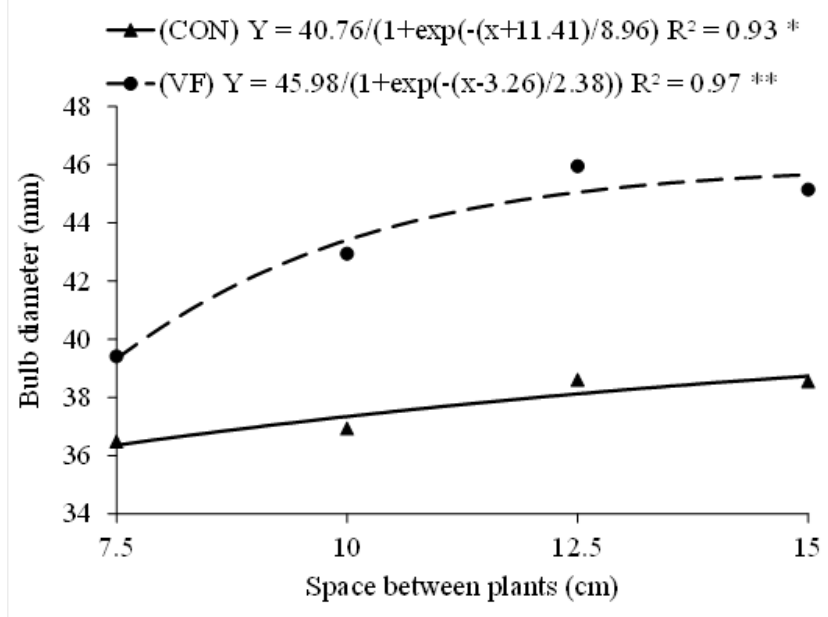

Figure 1. Bulb diameter of garlic from conventional (CON) and virus-free (VF) seeds as a function of spacing between plants.

Mengesha and Tesfaye (2015) found similar results for garlic plants of the Chiro cultivar (Ethiopian variety) grown with spacings of 10, 15, and $20 \mathrm{~cm}$ between plants and $30 \mathrm{~cm}$ between rows; they found increases in $\mathrm{BD}$ as the spacing was increased: the largest BD (34.59 mm) was found with the spacing of $20 \mathrm{~cm}$ and the lower BD (30.44 $\mathrm{mm}$ ) with the spacing of $10 \mathrm{~cm}$. However, Doro (2012) compared four spacings between plants (5, 10,15 , and $20 \mathrm{~cm}$ ) and found no variation in BD between the spacings of 10 and $15 \mathrm{~cm}$, while the

A

$\rightarrow \mathrm{Y}=35.83-0.124 \times \mathrm{R}^{2}=0.99 * *$

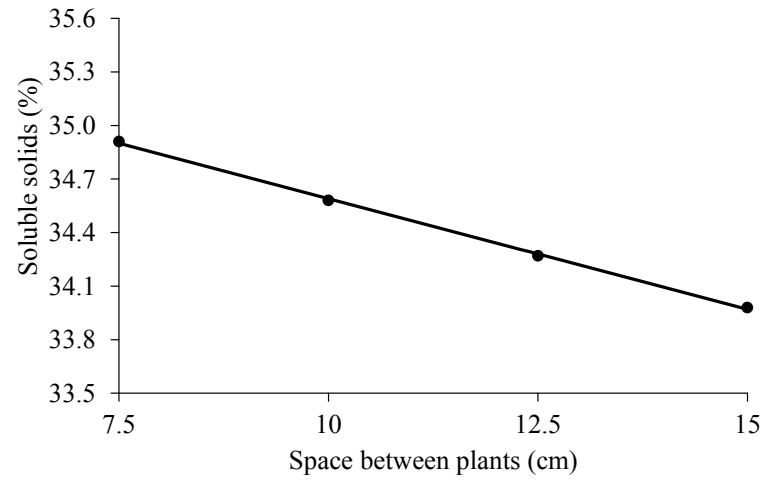

$\mathrm{C}$

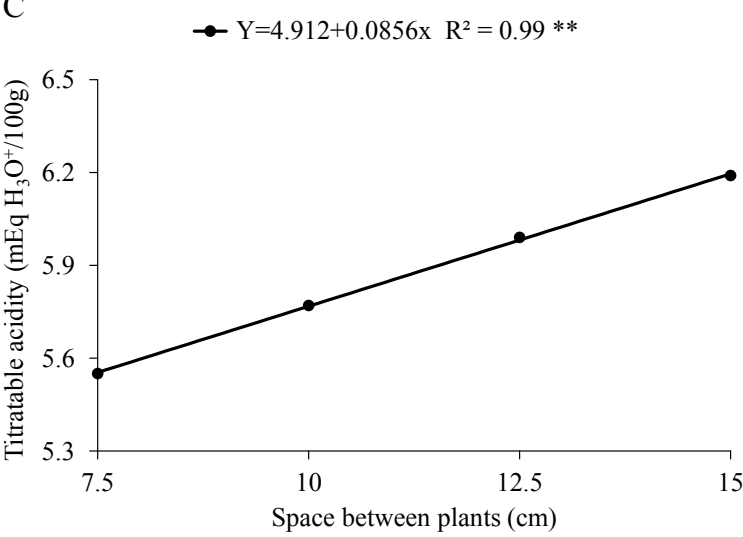

Figure 2. Soluble solids (SS) (A), total soluble sugars (TSS) garlic as a function of spacing between plants. spacing of $20 \mathrm{~cm}$ resulted in greater BD when compared to the spacings of 5 and $10 \mathrm{~cm}$.

According to the results of soluble solids (SS) content as a function of spacing between plants, the highest SS was found in the spacing of $7.5 \mathrm{~cm}$ $(34.93 \%)$, and it decreased up to the spacing of 15.0 cm (Figure 2A).

Total soluble sugars (TSS) also decreased as the space between plants was increased, reaching a maximum of $24.39 \%$ in the spacing of $7.5 \mathrm{~cm}$ (Figure 2B).

B

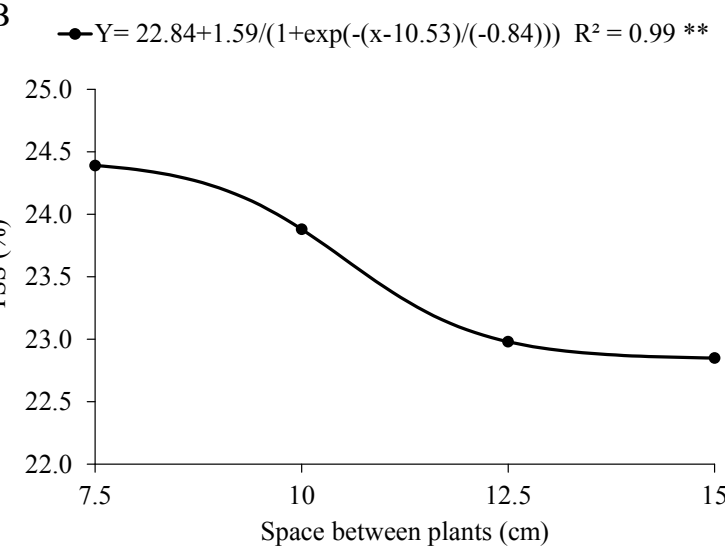

D $\rightarrow \mathrm{Y}=7.12-0.108 \times \mathrm{R}^{2}=0.99 * *$

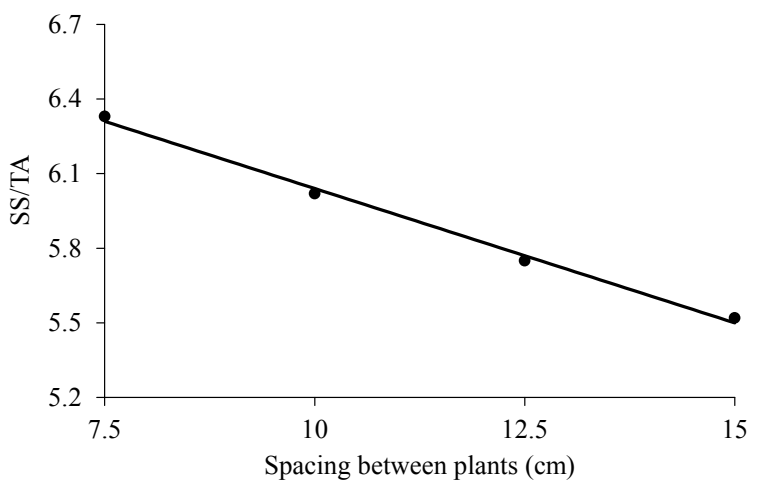

Rev. Caatinga, Mossoró, v. 32, n. 4, p. 966 - 975, out. - dez., 2019 
According to Vidya et al. (2013), decreases in SS and TSS may be due to a greater transpiration caused by the larger space between plants; the plants remain photosynthetically active with higher energy consumption than those grown in smaller spacing with lower transpiration, which use stored carbohydrates, thus, decreasing SS production.

The SS contents in garlic bulbs vary mainly due to the cultivar $x$ environment interaction and bulb maturity at harvest, since the bulb maturation and ripening cause hydrolysis of starch and make complex sugars become simple sugars (CHITARRA; CHITARRA, 2005). These contents may also vary slightly as a function of cultural practices used before, during, and after harvest, as found in the present study for the variation in plant density.

Vidya et al. (2013) evaluated five garlic planting densities and found highest SS content $(27.17 \%)$ using the smallest spacing $(10 \times 5 \mathrm{~cm})$, and the lowest $(25.95 \%)$ using the largest spacing $(20 \times 7.5 \mathrm{~cm})$; in addition, they found similar results for TSS, with the highest one $(7.8 \%)$ with the spacing of $20 \times 7.5 \mathrm{~cm}$, which was below those found in the present study. High sugar contents, especially reducing sugars such as glucose and fructose, is valued for production of black garlic. Garlic with high fructose content is the most suitable to produce black garlic due to its characteristic sweet flavor and a less typical garlic odor during heat treatment (BOTREL; OLIVEIRA 2012).

Olfati et al. (2016) evaluated physicochemical characteristics of garlic with different spaces between plants $(15,25$, and $35 \mathrm{~cm})$ and found no differences in SS contents, indicating that spacings larger than $15 \mathrm{~cm}$ have no effect on this characteristic in garlic bulbs.

Garlic from large seed cloves had higher titratable acidity (TA) than those from small seed cloves (Table 1). Garlic plants from virus-free seeds had higher TA than those from conventional seeds (Table 3). The TA increased growth as the space between plants was increased, from $5.51(7.5 \mathrm{~cm})$ to $6.13 \mathrm{mEq} \mathrm{H}_{3} \mathrm{O}^{+} 100 \mathrm{~g}^{-1}(15 \mathrm{~cm})$ (Figure 2C).

Variations in TA are usually related to genetic characteristics of the cultivar and the crop environment. Soares (2013) found TA means of 5.33 to $7.76 \mathrm{mEq} \mathrm{H}_{3} \mathrm{O}^{+} 100 \mathrm{~g}^{-1}$ in eleven garlic cultivars in Governador Dix-sept Rosado, Rio Grande do Norte (RN), Brazil. Lucena et al. (2016) evaluated the garlic BRS-Hozan cultivar and found TA of 5.82 to $6.54 \mathrm{mEq} \mathrm{H} \mathrm{H}_{3}^{+} 100 \mathrm{~g}^{-1}$ in Governador Dix-sept Rosado, and 4.64 to $8.44 \mathrm{mEq} \mathrm{H}_{3} \mathrm{O}^{+} 100 \mathrm{~g}^{-1}$ in Baraúna, RN.

Table 3. Titratable acidity, and soluble solids to titratable acidity ratio (SS/TA) of garlic bulbs as a function of garlic seed health.

\begin{tabular}{ccc}
\hline Seed health & $\begin{array}{c}\text { Titratable acidity } \\
\left(\mathrm{mEq} \mathrm{H}_{3} \mathrm{O}^{+} 100 \mathrm{~g}^{-1}\right)\end{array}$ & SS/TA \\
\hline Conventional & $5.74 \mathrm{~b}$ & $6.06 \mathrm{a}$ \\
Virus-free & $6.01 \mathrm{a}$ & $5.75 \mathrm{~b}$ \\
\hline
\end{tabular}

Means followed by the same letter in the column do not differ by Student's t-test $(p \leq 0.05)$.

TA is important for industry because the higher the acidity the better the garlic's industrial characteristics (CHAGAS et al., 2003). TA is directly related to organic acid contents in vegetables and is one of the indicators of flavor and aroma (BESSA et al., 2017).

The small seed cloves resulted in bulbs with higher SS to TA ratio than the large seed cloves (Table 1). The SS to TA ratios of plants from virusfree seeds were lower (5.75) than those of plants from conventional seeds (6.06) (Table 3). Regarding the planting spacings, the highest SS to TA ratio was found in the plants grown with spacing of 7.5 (6.35), and the lowest in the those grown with spacing of $15.0 \mathrm{~cm}$ (5.56) (Figure 2D).

The reductions in SS to TA ratio due to the use of virus-free garlic seeds, large seed cloves, and great planting spacing were mainly due to the increase of acidity in these treatments; the garlic seed health and seed clove size did not affect the soluble solid contents, which decreased as the space between plants was increased. Thus, the higher TA content and lower SS to TA ratio in these treatments indicate a more intense aroma of the bulbs due to the higher content of some acids, which is a characteristic desired by consumers (CHAGAS et al., 2003).

The SS to TA ratio is important to evaluate the postharvest quality of vegetables. It is more representative than isolated measurements of sugars or acidity and denotes the balance between sugars and acids that can be used as a criterion for evaluation of aroma and flavor (CHITARRA; CHITARRA, 2005). Lopes et al. (2016) found SS to TA ratio of 4.42 to 5.91 for the garlic Roxo Pérola de Caçador cultivar in Baraúna, RN. Soares (2013) found SS to TA ratio of 3.96 to 6.16 in eleven garlic cultivars. The garlic pungency varied according to the seed health; plants from virus-free seeds had higher means compared to those from conventional seeds (Table 4). 
Table 4. Pungency, total solids, and industrial index of garlic as a function of seed health.

\begin{tabular}{cccc}
\hline Seed health & $\begin{array}{c}\text { Pungency }(\mu \text { Mols of pyruvic } \\
\left.\text { acid } \mathrm{mL}^{-1}\right)\end{array}$ & Total solids $(\%)$ & Industrial index \\
\hline Conventional & $78.29 \mathrm{~b}$ & $35.21 \mathrm{a}$ & $27.57 \mathrm{~b}$ \\
Virus-free & $85.97 \mathrm{a}$ & $34.71 \mathrm{~b}$ & $29.83 \mathrm{a}$ \\
\hline
\end{tabular}

Means followed by the same letter in the column do not differ by Student's t-test $(p \leq 0.05)$.

The pungency increased as the plant spacing was increased, mainly from the spacing of 10.0 to $12.5 \mathrm{~cm}$; the minimum pungency was $79.59 \mu \mathrm{Mols}$ of pyruvic acid $\mathrm{mL}^{-1}(7.5 \mathrm{~cm})$ and the maximum was $84.55 \mu$ Mols of pyruvic acid $\mathrm{mL}^{-1}(15.0 \mathrm{~cm})$ (Figure $3 \mathrm{~A})$.

The highest pyruvic acid contents in the bulbs were found in treatments that allowed a better acclimatization of the plants to the crop conditions, when was also observed a greater vegetative vigor in the field.

According to Taiz and Zeiger (2013), the plant uses carbon dioxide and water to obtain glucose through the energy of sunlight during photosynthesis; the glucose is, then, broken in the glycolysis, producing pyruvic acid. This can be confirmed by the combination of the virus-free seeds and the larger spacings between plants, in which plants with higher vegetative vigor were found and, consequently, they had higher pyruvic acid contents in the bulbs.

Pungency in garlic is proportional to pyruvic acid content; determining the content of pyruvic acid in garlic extracts is a simple measure of pungency (VARGAS et al., 2010; SOARES, 2013). It is important for choosing the raw material for industries. According to Feimberg (1973), the higher the pungency of the raw material the more pungent the final product, i.e., bulbs with higher pyruvic acid contents will result in industrial products with better characteristics of flavor and aroma.

Chagas et al. (2003) found lower pungency in garlic plants grown in Lavras, Minas Gerais, Brazil, with means of 46.20 to $55.01 \mu$ Mols of pyruvic acid $\mathrm{g}^{-1}$, using semi-noble cultivars. However, Lopes et al. (2016) evaluated the Roxo Pérola de Caçador cultivar and found similar pungency results (80.59 to $99.40 \mu$ Moles of pyruvic acid $\mathrm{mL}^{-1}$ ) to those found in the present study.
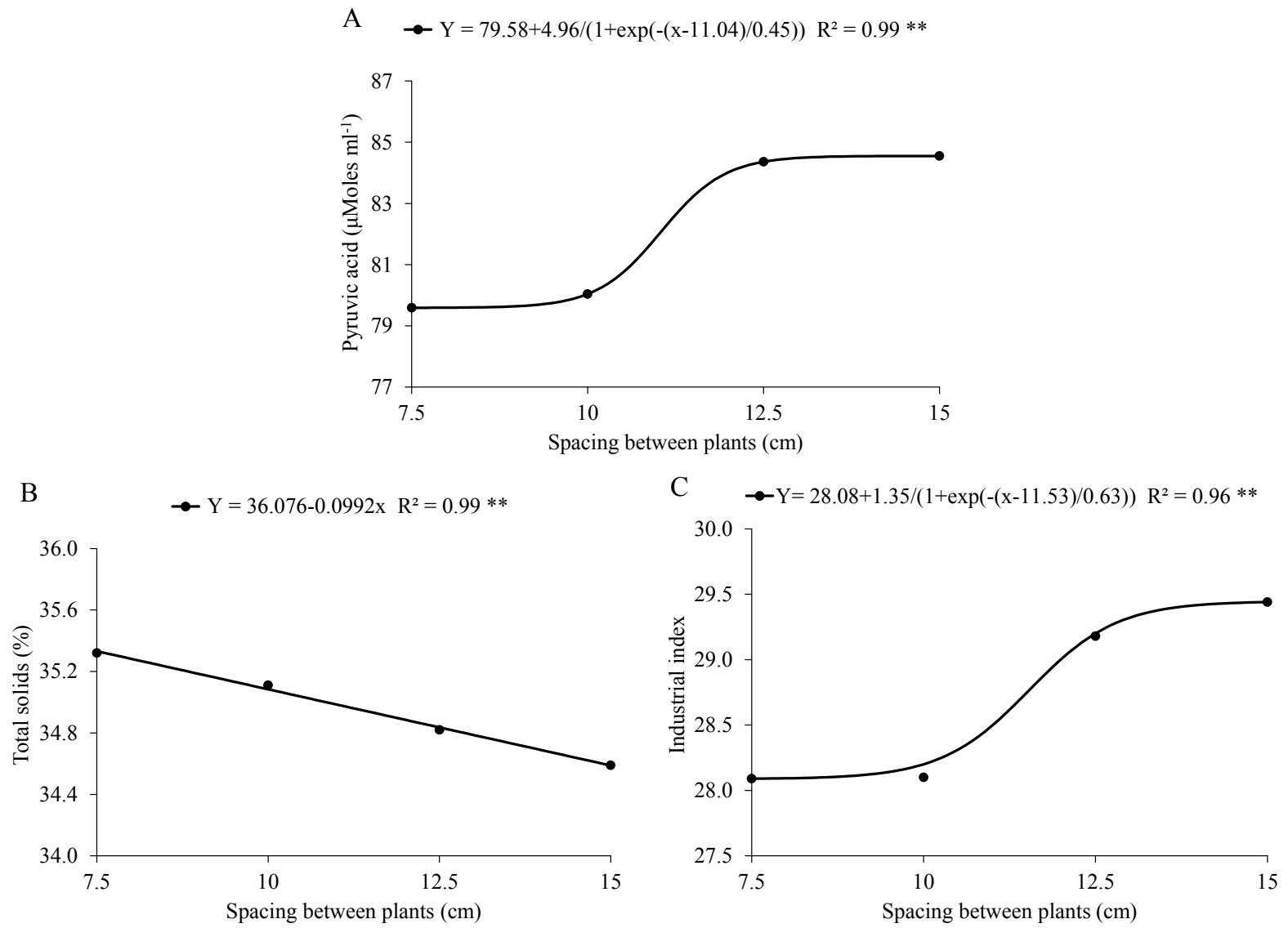

Figure 3. Pungency (A), total solids (B), and industrial index (C) of garlic as a function of spacing between plants. 
Plants from virus-free seeds had lower total solid contents (TS) $(34.71 \%)$ than those from conventional seeds (35.21\%) (Table 4).

The TS decreased exponentially as a function of plant spacing, with maximum and minimum estimates of 35.35 and $34.62 \%$ at 7.5 and $15.0 \mathrm{~cm}$, respectively (Figure 3B). This reduction may be related to the higher bulb weight of plants from virus -free seeds and the larger space between plants, resulting in a higher amount of water in them, which reduced TS concentrations. However, high TS contents (above 30\%) were found in all treatments, which is desirable for processing, resulting in a higher industrial yield (CHAGAS et al., 2003).

According to Chitarra and Chitarra (2005), bulbs with high total solids contents (above 30\%) have better postharvest conservation capacity. The results found in the present study show the high potential of the garlic bulbs for postharvest storage due to their high TS contents and their good prospects for industrialization.

The industrial index in plants from virus-free seeds (29.83) was higher than that of plants from conventional seeds (27.57) (Table 4).

Considering the spacing between plants and pungency (Figure 3A), the industrial index showed a sigmoid model with minimum estimate of 28.09 in the spacing of $7.5 \mathrm{~cm}$, increasing from the spacing of $10.0 \mathrm{~cm}$ and reaching $29.22 \mathrm{~cm}$ in the spacing of $12.5 \mathrm{~cm}$, with a tendency of stabilization; and a maximum estimate of 29.44 in the spacing of $15 \mathrm{~cm}$ (Figure 3C).

Industrial index is important when producing dehydrated garlic. It denotes the association of TS contents with pyruvic acid (LUCENA, et al., 2016). Thus, despite the lower TS content of bulbs from the virus-free seeds and the larger evaluated spacings between plants, the highest pyruvic acid contents (pungency) in these treatments were more expressive, resulting in a higher industrial index, higher yield, and products with more pronounced aroma.

The aroma of the processed product is directly related to the high initial pyruvic acid contents of the bulbs, which contributes to a better acceptance of this vegetable as a condiment, either in fresh or industrialized form.

The results of the present work indicate that the garlic produced can be recommended for the industry by presenting good flavor and aroma and high pungency and industrial index, regardless of the garlic seed health, seed clove size, and space between plants used.

\section{CONCLUSION}

The use of large seed cloves of garlic results in plants with bulbs of larger diameters and higher titratable acidity.
Contents of soluble solids, total soluble sugars, soluble solids to titratable acidity ratio, and total solids decrease as the space between plants is increased, regardless of seed health and clove size.

Virus-free garlic seeds planted with space between plants of 12.5 and $15.0 \mathrm{~cm}$ generate plants with bulbs of larger diameter and higher titratable acidity, pungency, and industrial index, enabling the production of better-quality bulbs with good prospects for industrialization.

\section{ACKNOWLEDGEMENT}

This work was carried out with the support of the Brazilian Coordination for the Improvement of Higher Education Personnel (CAPES) - Financing Code 001

\section{REFERENCES}

AHMED, I. et al. Impact of plant spacing on garlic rust (puccinia allii), bulb yield and yield component of garlic (Allium sativum). Pakistan Journal of Agricultural Research, v. 30, n. 4, p. 380-385, 2017.

ASSOCIATION OF OFFICIAL ANALYTICAL CHEMISTRY - AOAC. Official methods of analysis of the Association of Official Analytical Chemistry. Washington: AOAC, 2002. 1115 p.

BESSA, A. T. M. et al. Caracterização físicoquímica de alho 'BRS Hozan' e 'Roxo Pérola de Caçador' em função do tempo de armazenamento. Revista Colombiana de Ciencias Hortícolas, v. 11, n. 2, p. 368-377, 2017.

BOTREL, N.; OLIVEIRA, V. R. Cultivares de cebola e alho para processamento. In: CONGRESSO BRASILEIRO DE OLERICULTURA， 52，2012, Salvador. Anais... Brasília: Associação Brasileira de Horticultura, 2012. p. S8420-S8434.

CARVALHO, V. D. et al. Tempo de armazenamento na qualidade do alho cv. Amarante. Pesquisa Agropecuária Brasileira, v. 26, n. 10, p. 16791684, 1991.

CAVALCANTI, F. J. A. Recomendações de adubação para o estado de Pernambuco: segunda aproximação. 3. ed. Recife, PE: IPA, 2008. 212 p.

CASTELLANOS, J. Z. et al. Garlic productivity and profitability as affected by seed clove size, planting density and planting method. HortScience, v. 39, n. 6, p. 1272-1277, 2004. 
CHAGAS, S. J. R. et al. Características qualitativas de cultivares de Alho no sul de Minas Gerais. Ciência e Agrotecnologia, v. 27, sup., p. 1584-1588, 2003.

ChItARRA, M. I. F.; ChITARRA, A. B. Póscolheita e frutos e hortaliças: fisiologia e manuseio. 2. ed. Lavras, MG: UFLA, 2005. 785 p.

DORO, A. K. Response of garlic (allium sativum L) to intra-row spacing at ajiwa irrigation site of Katsina state - Nigeria. Journal of Research in National Development, v. 10, n. 2, p. 103-107, 2012.

EMPRESA BRASILEIRA DE PESQUISA AGROPECUÁRIA - EMBRAPA. Sistema brasileiro de classificação de solos. Brasília-DF: Embrapa, 2018. 590 p.

FEIMBERG, B. Vegetables. In: ARSDEL, W. B. V.; COPLEY, M. J; MORGAN JÚNIOR, A. I. (Eds.). Food Dehydratation. New York: AVI, 1973. v. 2, p. 43-55.

HENRIQUES, G. P. S. A. Resposta do alho nobre vernalizado à adubação nitrogenada nas condições de cultivo do semiárido tropical. 2016. 94 f. Tese (Doutorado em Fitotecnia: Área de Concentração em Práticas Culturais) - Universidade Federal Rural do Semi-Árido, Mossoró, 2016.

INSTITUTO ADOLFO LUTZ - IAL. Métodos físico-químicos para análise de alimentos. 4. ed. São Paulo-SP, 2005. 533 p.

LOPES, W. A. R. et al. Caracterização físicoquímica de bulbos de alho submetido a períodos de vernalização e épocas de plantio. Horticultura Brasileira, v. 34, n. 2, p. 231-238, 2016.

LENCHA, B.; BUKE, T. Effects of clove size and plant density on the bulb yield and yield components of garlic (Allium sativum L.) in Sodo Zuria Woreda, southern wolaita zone. Journal of Natural Sciences Research, v. 7, n. 21, p. 1-7, 2017.

LUCENA, R. R. M. et al. Qualitative analysis of vernalizated semi-noble garlic cultivars in western Rio Grande do Norte State, Brazil. Revista Caatinga, v. 29, n. 3, p. 764-773, 2016.

MAHADEEN, A. Y. Influence of clove weight on vegetative growth and yield of garlic (Allium sativum L.) grown under drip irrigation. Jordan Journal of Agricultural Sciences, v. 7, n. 1, p. 44-50, 2011.

MARODIN, J. C. Produtividade de alho em função da sanidade e tamanho do alho semente e da densidade de plantio. 2014. 97 f. Tese
(Doutorado em Fitotecnia: Área de Concentração em Produção Vegetal) - Universidade Federal de Lavras, Lavras, 2014

MENGESHA, W.; TESFAYE, A. Effect of spacing in incidence and severity of garlic rust (Puccinia allii) and bulb yield and related traits of garlic at eastern Ethiopia. Plant Pathology and Microbiology, v. 6, n. 10, p. 314-317, 2015.

MORAVČEVIĆ, D. et al. Effect of plant density on the characteristics of photosynthetic apparatus of garlic (Allium sativum var. vulgare L.). African Journal of Biotechnology, v. 10, n. 71, p. 1586115868,2011

MUNEER, N. et al. Effect of planting density on growth, yield and quality of Garlic at Rawalakot, Azad Kashmir. International Journal of Agronomy and Agricultural Research, v. 10, n. 1, p. $42-51,2017$.

OLFATI, J. et al. Between-row spacing and local accession on the yield and quality of garlic. Comunicata Scientiae, v. 7, n. 1, p. 112-121, 2016.

OLIVEIRA, F. L. et al. Características agronômicas de cultivares de alho em Diamantina. Horticultura Brasileira, v. 28, n. 3, p. 355-359, 2010.

RANDLE, W. M. Onion flavor chemistry and factors influencing flavor intensity. ACM Symposium Series, v. 660, n. 1, p. 41-42, 1997.

REGINA, S. M.; RODRIGUES, J. J. V. Peneiras já classificam o alho-planta: informações técnicas. 1. ed. Belo Horizonte, MG: ACAR, 1970. 6 p.

RESENDE, J. T. V. et al. Caracterização morfológica, produtividade e rendimento comercial de cultivares de alho. Horticultura Brasileira, v. 31 , n. 1, p. 157-162, 2013.

RESENDE, F. V. et al. Crescimento e produção de clones de alho provenientes de cultura de tecidos e de propagação convencional. Scientia Agricola, v. 57 , n. 1 , p. $61-66,2000$

SCHWIMMER, S.; WESTON, W. J. Enzymatic development of pyruvic acid in onion as a measure of pungency. Journal of Agricultural and Food Chemistry, v. 4, n. 9, p. 303-304, 1961

SOARES, A. M. Avaliação de cultivares de alho no município de Governador Dix-sept RosadoRN. 2013. 104 f. Dissertação (Mestrado em Agronomia: Área de Concentração em Práticas Culturais) - Universidade Federal Rural do SemiÁrido, Mossoró, 2016. 
TAIZ, L.; ZEIGER, E. Fisiologia Vegetal. 5. ed. Porto Alegre, RS: Artmed, 2013. 918 p.

VARGAS, V. C. S. et al. Efecto de la interacción genotipo-ambiente sobre la expresión del contenido de allicina y ácido pirúvico en ajo (Allium sativum L.). Revista FCA UNCuyo, v. 42, n. 2, p. 15-22, 2010 .

VIDYA, G. et al. Effect of planting time and plant densities on yield, quality and cost of production in garlic (Allium sativum L.) cv. Jamnagar. The Asian Journal of Horticulture, v. 8, n. 2, p. 552-555, 2013.

YEMM, E. W.; WILLIS, A. J. The estimation of carbohydrates in plant extracts by anthrone. Biochemical Journal, v. 57, n. 1, p. 508-514, 1954. 